\title{
ВЛИЯНИЕ ЗАПОВЕДНОГО РЕЖИМА НА РАЗВИТИЕ ГОРНОГО РЕЛЬЕФА ЦЕНТРАЛЬНОЙ АЗИИ (НА ПРИМЕРЕ ЗАПОВЕДНИКА АКСУ-ДЖАБАГЛЫ)
}

\author{
(С) 2020 г. С. А. Буланов* \\ Институт географии РАН, Москва, Россия \\ *e-mail: bulanov@igras.ru \\ Поступила в редакцию 05.04.2019 г. \\ После доработки 05.10.2019 г. \\ Принята к публикации 28.11.2019 г.
}

\begin{abstract}
Старейший в горах Центральной Азии заповедник Аксу-Джабаглы был создан более 90 лет назад. За эти годы природоохранный режим оказал существенное влияние не только на биоту, но и на экзогенные процессы на территории резервата. С целью оценки этого влияния проведены специальные геоморфологические исследования. Было проведено типологическое районирование горного рельефа территории заповедника во всех высотных ярусах: высокогорье, среднегорье и низкогорье. Выделена переходная зона, характеризующая крупные тектонические уступы. Для каждого типа рельефа определены характерные изменения протекания геоморфологических процессов, связанные с прекращением антропогенной нагрузки преимущественно в виде выпаса и с поддержанием режима особо охраняемой территории. Установлено, что на территории заповедника преобладает общая тенденция к стабилизации склоновых процессов, более заметная в нижнем ярусе гор и практически отсутствующая в высокогорье. Обратная тенденция - к активизации процессов - отмечается в двух геоморфологических обстановках: в альпийском высокогорье и в очагах развития оползней в переходной зоне от высокогорья к среднегорью.
\end{abstract}

Ключевые слова: высокогорье, среднегорье, низкогорье, экзогенные процессы, лавины, сели, оползни, выпас, активизация, стабилизация

DOI: $10.31857 / \mathrm{S} 2587556620020041$

\section{ВВЕДЕНИЕ}

В 2016 г. исполнилось 90 лет со дня образования заповедника Аксу-Джабаглы в западных отрогах Тянь-Шаня - первого не только в Казахстане, но и во всем горном регионе Центральной Азии [7]. Установление режима особо охраняемой территории на столь продолжительный срок повлияло на все компоненты ландшафта, в том числе и на рельеф, что можно отметить, прежде всего, в отношении условий протекания экзогенных процессов. Впрочем, следует отметить, что геоморфологическое строение охраняемых территорий редко выступает в качестве основного объекта исследований, не стал исключением в этом отношении и Аксу-Джабаглы. Как штатные сотрудники самого заповедника, так и большинство посещающих его исследователей основное внимание уделяли биоте, лишь изредка упоминая о чрезвычайных событиях в виде катастрофических проявлений оползней, обвалов, селей, как правило, кратко отмечая их в летописи природы без анализа причин, установки мониторинговых наблюдений и прогноза дальнейшего развития событий $^{1}$ [14]. Разумеется, эти наблюдения не могли отразить все многообразие и специфику связей между рельефом и прочими компонентами ландшафта заповедника, тем более установить тенденцию изменения этих связей в условиях ООПТ.

В 1980-х годах Институт географии АН СССР организовал в заповедники Средней Азии ряд комплексных экспедиций, в состав которых входили также специалисты-геоморфологи. Они должны были не только дать общую характеристику рельефа территории, но и оценить влияние на него режима строгой охраны и компенсировать указанный выше пробел [2]. В качестве базового был выбран заповедник Аксу-Джабаглы как по причине длительности заповедного режима 2 ,

\footnotetext{
${ }^{1}$ Единственное исключение - попытка количественной оценки сотрудниками заповедника в 1979-1982 гг. разрастания оползней в ур. Жетымсай на западной границе, частично за ее пределами (см. ниже).

${ }^{2}$ Наземная стереофотограмметрическая съемка осуществлялась с помощью оборудования фирмы “Карл Цейсс", Йена.
} 
так и из-за репрезентативности заповедных ландшафтов: на сравнительно небольшой территории (около 130000 га) $)^{2}$ представлены многие типы и комплексы рельефа, характерные не только для гор Западного Тянь-Шаня, но и гор Центральной Азии в целом. С 1982 по 1987 г. почти ежегодно проводились маршрутные исследования, охватившие все высотные пояса в горах заповедника и его окрестностей, были заложены несколько базисов НСС и произведена съемка с них наиболее типичных и динамичных геоморфологических объектов с целью проведения высокоточных измерений их динамики. К сожалению, эти работы, которые требовали повторных наблюдений, через продолжительные промежутки времени остались на начальной стадии и после распада СССР не получили развития. Тем не менее, полученные материалы были обобщены и послужили основой для типологии рельефа заповедника, с привлечением данных дистанционного зондирования [1, 4].

Следует отметить, что история заповедника событиями разного плана и разной степени влияния на его ландшафты, в том числе нарушениями природоохранного режима. Прежде всего, это неоднократное изменение его площади, которое, как правило, шло в сторону его расширения [9] и которое можно оценивать как положительный факт. С другой стороны, имели место случаи нарушения заповедного режима, которые выражались в рубках леса и сборе сухостоя, в “лесокультурных" работах в виде посадок деревьев, в выпасе скота, в браконьерстве, в пожарах, в сенокошении, в организации пчеловодства и даже в проведении в заповеднике геологоразведочных работ, не говоря уже о “плановой" рекреационной нагрузке: в 1960-е годы число посетителей достигало 1500 человек в год и более [6]. Нарушения фиксировались локально, главным образом на западной, отчасти на северной периферии заповедника. Пик этой деятельности пришелся на послевоенные годы вплоть до конца 1970-х. Последние 40 лет наблюдается возврат к строгому соблюдению заповедного режима и в целом мы оцениваем предшествующие отклонения от него малозначительными с точки зрения влияния на геоморфологические процессы в пределах охраняемой территории и на репрезентативность приводимой в данной статье оценки.

\section{ОРОГРАФИЯ И МОРФОСТРУКТУРА}

Территория заповедника охватывает субширотно ориентированные отроги на севере западного окончания Таласского Алатау - горы и хребты (с С на Ю): Жебаглытау, Алатау, Бугулутуртау, Аксутау; а также северный склон Угамского хр. с отрогом Балдабректау, западный склон главной орографической оси Таласского Алатау и каньон p. Аксу, врезанный в предгорное плато на западе.
Размах высот в пределах заповедника составляет почти 3000 м. Высшая его точка - Сайрамский пик - поднимается на 4230 м над ур. м. на Ю3 периферии заповедника. Наиболее низко расположены: русло р. Аксу (1260 м над ур. м.) в каньоне на западной границе и ур. Талдыбулак в месте его выхода на предгорную равнину (1300 м над ур. м.) на С3. Большая часть территории заповедника находится выше 2000 м над ур. м.

В морфоструктурном отношении горы заповедника представляют собой глыбовые хребты и массивы, возрожденные и перестроенные новейшими поднятиями, сформировавшимися на консолидированных породах палеозойских складчатых комплексов [4, 5]. В зависимости от интенсивности новейших поднятий выделяются высотные ступени, выраженные высокогорьем, среднегорьем и низкогорьем.

Соответственно, в пределах заповедника выделяется три яруса горного рельефа, каждый из которых включает несколько типов с характерными ландшафтами, а также переходная зона (рис. 1). Выделение ярусов основывалось, прежде всего, на преобладающих высотах вершин. В каждом ярусе в свою очередь были выделены несколько типов рельефа, имеющие отличные от прочих морфологию, морфометрию, ландшафтные и историко-генетические характеристики. Для каждого типа рельефа произведена оценка реакции геоморфологических процессов на установление режима особо охраняемой территории.

Высокогорье охватывает более примерно 2/3 охраняемой территории, прежде всего гребневые зоны крупных хребтов (кроме Жебаглытау) с вершинами выше 2800 м над у. м., прилегающие к ним склоны и долины дренирующих рек. Геоморфологическое строение его весьма разнообразно, что позволяет выделить 4 типа высокогорного рельефа: альпийский, эрозионный, округловершинный и депрессионный.

Альпийский рельеф типичен для гребневых зон хребтов, поднимающихся выше 3500 м над ур. м. Характеризуется глубокой ледниковой проработкой, происходившей в течение плейстоцена, вследствие чего здесь преобладают гляциальные формы рельефа: кары, троги и др.; здесь же сосредоточены практически все ныне существующие ледники. Широкие (первые сотни метров) днища U-образных троговых долин спускаются до абс. отметок 2300-2500 м над ур. м., ниже ледников они заняты моренными грядами, окружены крутыми, доходящими до отвесного состояния, бортами. Отчетливо выражена экспозиционная асимметрия хребтов высокогорья: ледники и связанные с ними формы рельефа приурочены, как правило, к затененным северным и подветренным восточным склонам, в то время как противоположные южные и западные - не имеют ледников и были, 


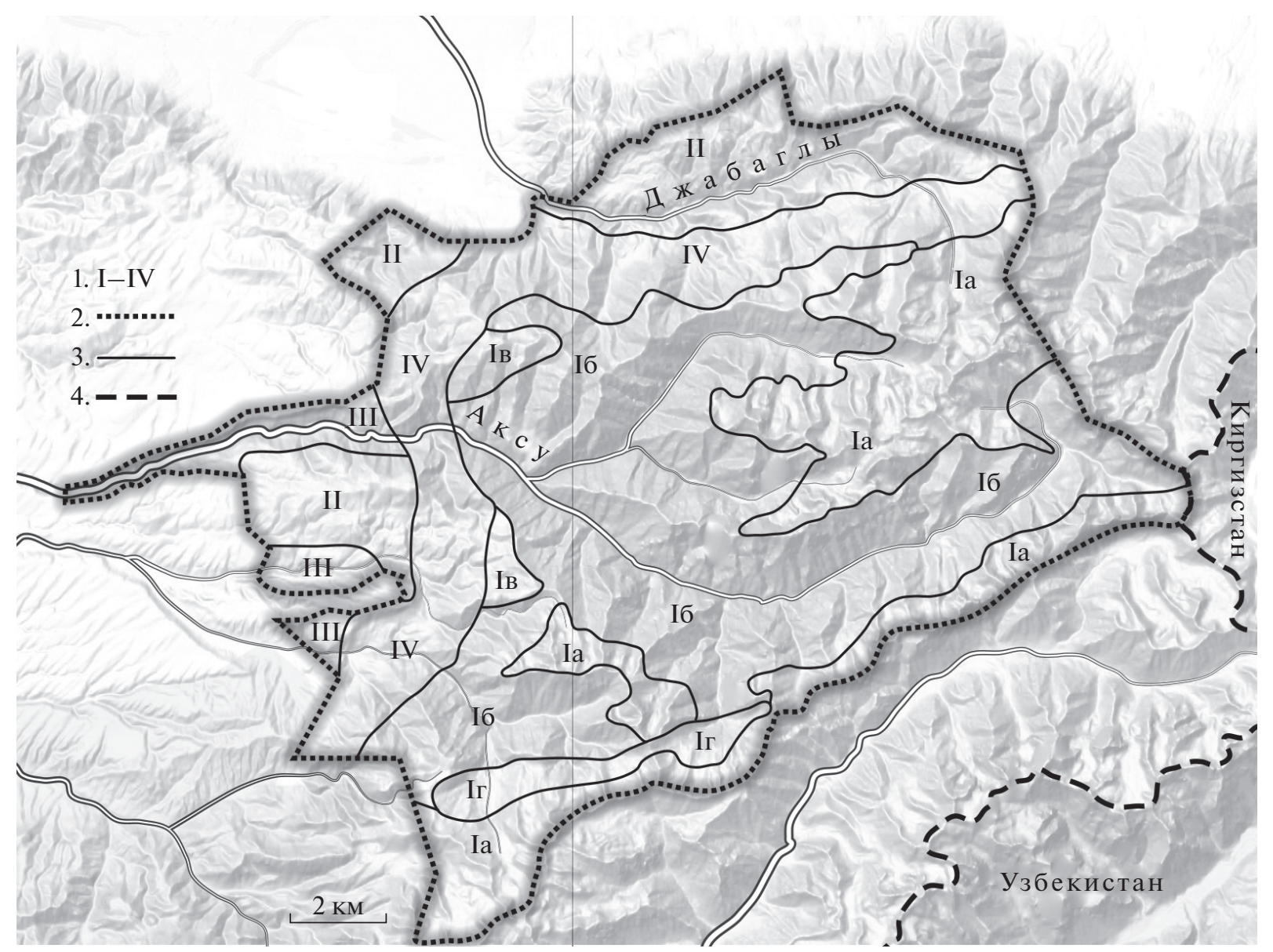

Рис. 1. Типы горного рельефа заповедника Аксу-Джабаглы.

Условные обозначения: 1 - ярусы и типы рельефа: I - высокогорье: Іа - альпийский тип, Іб - эрозионный тип, Ів округловершинный тип, Іг - депрессионный тип; II - среднегорье (плоскогорье); III - низкогорье (плато); IV - переходная зона; 2 - границы заповедника; 3 - границы типов и ярусов рельефа; 4 - государственные границы; 5 - урочища: 1 - Талдыбулак, 2 - Жетымсай, 3 - Кши-Каинды, 4 - Улькен-Каинды, 5 - Байдак, 6 - Каскабулак, 7 - Саркрама, 8 - Топшаксаз, 9 - Ргайлы, 10 - Аксу, 11 - Чуулдак, 12 - Бала-Балдабрек, 13 - Дарбаза, 14 - Шунгульдук, 15 Бугулутор.

вероятно, свободны от них не только в настоящее время, но и плейстоцене.

Для приледниковых скал и каменных россыпей характерна лишь разреженная криофильная растительность, которая, тем не менее, в определенной мере в состоянии сдерживать движение обломков [8]. Исключение составляют конечноморенные гряды, где присутствуют заросли кустарников и лужайки с относительно плотным дерново-травянистым покровом. На этих площадках наблюдается довольно плотная сеть троп крупных млекопитающих, прежде всего копытных (горные козлы и бараны-архары). Здесь же отмечены и связанные с ними следы слабой активизации эрозии и криогенного переноса рыхлого материала. Альпийское высокогорье заповедника, очевидно, было крайне труднодоступно всегда, поэтому вряд ли оно когда-либо испытывало заметную антропогенную нагрузку в виде выпаса.
Наибольший интерес оно могло иметь для охоты, которая широко практиковалась на заповедной территории по крайней с неолита. Об этом можно судить по наскальным изображениям в ур. Каскабулак, что находится на высоте 3000 м над ур. м. [10]. Поэтому можно заключить: если режим строгой охраны привел к увеличению численности объектов животного мира [7, 14], то можно говорить об определенной, хотя и крайне незначительной, активизации процессов сноса в высокогорье. То же можно отметить для приледниковых скал и каменных россыпей: в маршрутах неоднократно наблюдались камнепады, связанные с прохождением стад копытных.

Эрозионное высокогорье располагается ниже альпинотипного как на склонах, так и по долинам рек. Оно формировалось во внеледниковых условиях при преобладании эрозии и нивально-гравитационных процессов, что привело к формиро- 


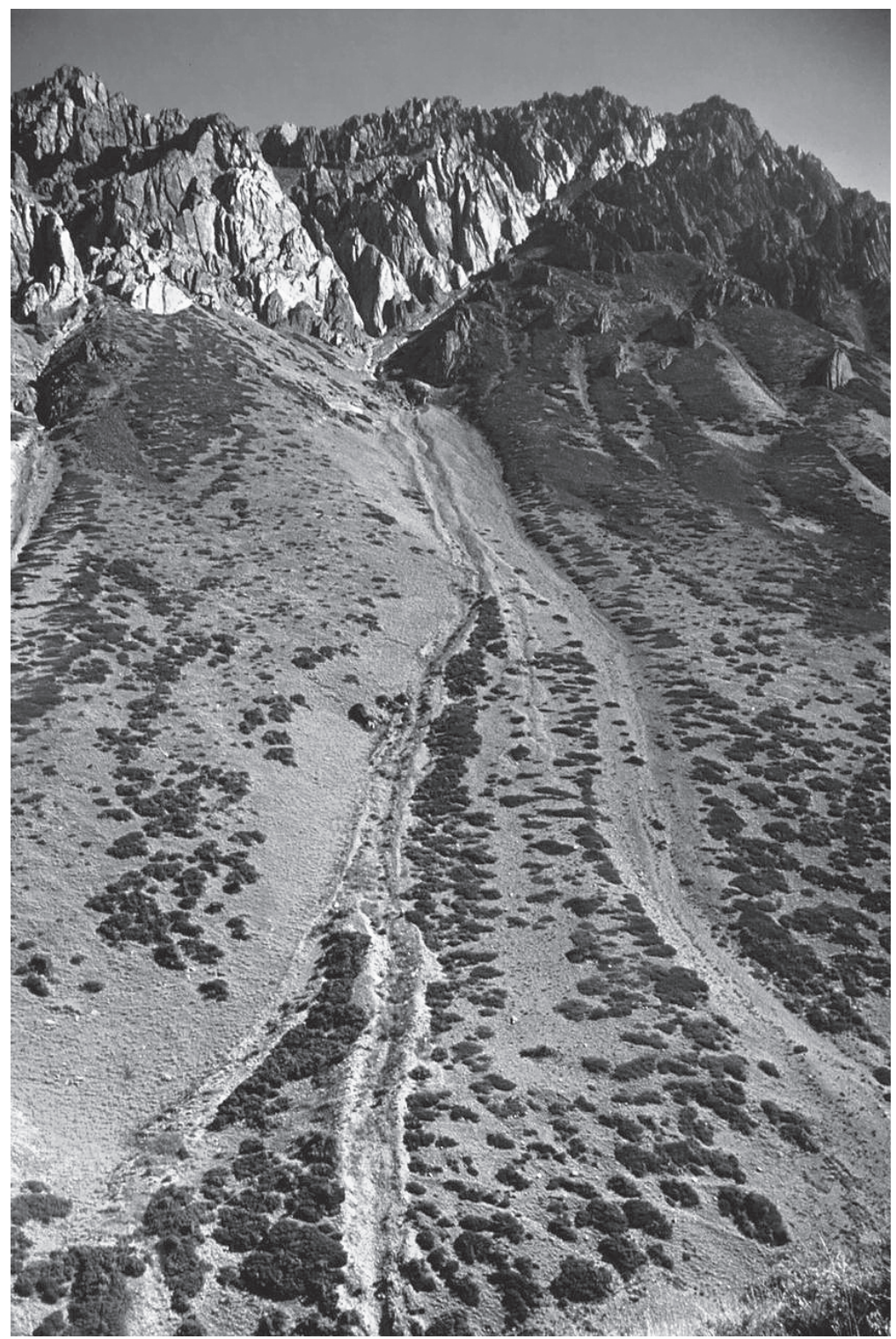

Рис. 2. Южный склон Алатау. Растительность крутых склонов высокогорья в пределах заповедника.

ванию глубоких (1-2 км) узких крутосклонных $\left(25^{\circ}-50^{\circ}\right.$, местами до $\left.90^{\circ}\right)$ ущелий. Характерны узкие пилообразные гребни и долины с V-образным поперечным профилем. Долинный комплекс редуцирован: узкое днище практически полностью занято валунистым руслом, пойма встречается фрагментарно, надпойменные террасы отсутствуют. Обломочные шлейфы обычно спускаются со склонов непосредственно в русло. Склоны, как правило, прямые, испешрены врезами-лотками, по которым в холодное время года сходят лавины, в теплое - селевые потоки [12].

Гребни скалистые, с редкой альпийской и субальпийской растительностью. Средние и нижние части склонов задернованы и покрыты травяно-кустарниковой растительностью на 50-80\%, остав- шееся пространство обычно занято обломочными шлейфами и скалами (рис. 2). Следует отметить почти повсеместное зарастание склонов, особенно в местах скопления рыхлых отложений у подножий, где встречаются фрагменты скотопрогонных троп, которые в настоящее время не используются. Вероятно, интенсивное зарастание склонов началось после прекращения выпаса, который до установления заповедного режима распространялся по долинам рек вплоть до альпийского пояса, о чем можно судить по характеру использования высокогорий за пределами охраняемой территории в настоящее время (рис. 3).

Тропы есть и выше по склонам, но, судя по их размерам и свежести, они до сих пор используются теми же копытными, что представлены в аль- 


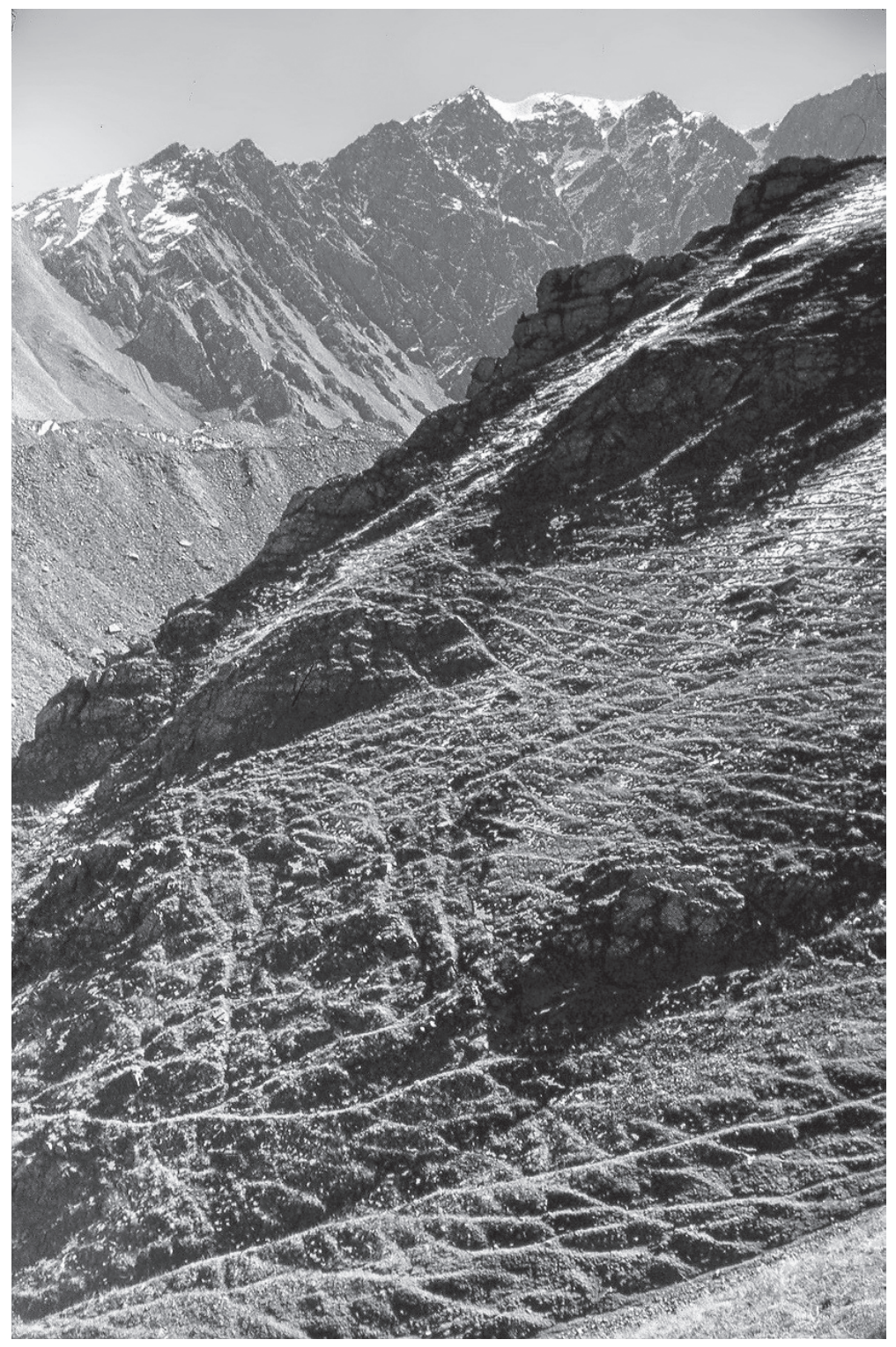

Рис. 3. Склоны высокогорья Таласского Алатау, подверженные выпасу, за пределами заповедника.

пийском поясе. Таким образом, мы имеем две противоположные тенденции: в верхнем ярусе наблюдается активизация процессов за счет увеличения поголовья диких копытных, в среднем и особенно нижнем наоборот - стабилизация, связанная с зарастанием склонов, находившихся некогда под выпасом. Однако однозначно связывать последнее обстоятельство с установлением заповедного режима, видимо, не стоит, поскольку в том же направлении может работать фактор изменения климата в виде уменьшения количества осадков в твердом виде и, соответственно, сокращения лавинно-эрозионной деятельности.

Округловершинная разновидность высокогорья имеет фрагментарное распространение на западных окончаниях хребтов Угамского, Алатау и в ур. Кызылбастау. Характеризуется широкими уплощенными вершинами в диапазоне высот 2800-3100 м над ур. м., активным протеканием криогенных процессов и обилием поздно тающих снежников, залегающих в выработанных ими понижениях - нивальных нишах. В остальном: по характеру склонов и днищ долин не отличается от описанного выше эрозионного высокогорья. Очевидно, что в прошлом вершины и часть прилегающих к ним склонов интенсивно использовались под выпас. В настоящее время отмечается зарастание приводораздельных пространств и снижение на них активности процессов сноса.

Депрессионная разновидность высокогорья в заповеднике представлена неширокой, сниженной относительно окружающих вершин и склонов, 
зоной, отражающая отстающую в поднятии тектоническую структуру к северу от Угамского хребта. Ее отличительные черты: небольшая глубина расчленения (первые сотни м), округлая форма вершин, широкие днища долин, плавные переходы в относительно пологие склоны. Абсолютные высоты при этом весьма велики - 29003300 м над ур. м. Долины, пересекающие депрессионную зону вкрест простирания, имеют котловинообразные расширения, занятые древними моренными грядами. Склоны и междуречья не имеют следов ледниковой обработки: в течение плейстоцена на них господствовали перигляциальные условия, сохраняющиеся и в настоящее время. При отсутствии значительных перепадов высот и крутых склонов наибольшее развитие здесь получили криогенные и нивально-криогенные процессы. Это еще один район высокогорья, где удалось обнаружить следы интенсивного выпаса, который закончился несколько позже, чем на основных участках, поскольку эта территория (бассейн р. Балдабрек) была присоединена к заповеднику в 30-х годах XX в. [6]. Среди примет выпаса - не только заросшие тропы и места скоплений скота (тырла) на морене и пологих склонах, но и практически полное отсутствие древесно-кустарниковой растительности, которая в изобилии имеется на соседних крутых и скалистых участках, принадлежащих другим типам рельефа.

Среднегорье выделяется по преобладанию вершин в высотном диапазоне от 1500-2800 м над ур. м. На него приходится примерно пятая часть территории заповедника, в основном на северной (горы Жебаглытау, фрагментарно на левобережье Джабаглы у подножия Алатау) и западной его периферии. Вершины обычно плоские, реже куполообразные, отчего средневысотные горные массивы Западного Тянь-Шаня часто можно рассматривать как плоскогорья. Рассекающие их долины также имеют вид ущелий, но, в отличие от высокогорных долин, глубина их (300-700 м), как и крутосклонность $\left(15^{\circ}-30^{\circ}\right)$, значительно меньше. По долинам хорошо развит пойменный комплекс.

Для среднегорья характерно безлесие. Исключение составляют прилегающие к руслам нижние части склонов, в основном северной экспозиции, а также приустьевая часть урочищ Кши- и УлькенКаинды, где сохранились высокоствольные арчевники. Последнее обстоятельство указывает на то, что безлесие связано с антропогенным фактором, прежде всего с выпасом. Последние 90 лет здесь идет восстановление растительности, в основном горных степей [8, 14]. Закрепление грунтов положительно сказывается на их противоэрозионной устойчивости, о чем можно судить по разнице в мутности временных водотоков, стекающих с заповедной территории и со склонов по соседству, находящихся в аграрном использовании, а также по пораженности последних эрозионными формами.

Низкогорье в пределах заповедника представлено также одним типом рельефа - платообразным. Собственно плато, сформированное на мощных пластах нижнечетвертичных конгломератов, принадлежит заповеднику только на ограниченных участках, а именно: в пределах узкой (100-200 м) полосы вдоль северного борта каньона Аксу и ур. Терсжайлау (междуречье Балдабрек-Бала-Балдабрек). В большей степени заповедный режим распространяется на характерные для плато элементы расчленения - каньоны, и в первую очередь на уникальный каньон р. Аксу (частично на каньоны рр. Балдабрек и Бала-Балдабрек). Абсолютные отметки плато колеблются в интервале 1400-1800 м над ур. м., глубина каньона Аксу на выходе из высокогорья - более 600 м, ниже уменьшается до 150 м (на западной границе заповедника). Однако по крутизне склонов - в среднем $25^{\circ}-50^{\circ}$, местами, главным образом в прибровочной части, отвесные, - они более похожи на высокогорные.

Как предшествующее использование, так и реакция на охраняемый режим, различны на плато и склонах каньона. До создания заповедника на плато произошла деградация почвенного покрова, очевидно из-за неумеренного выпаса. В прибровочной части плато почва уничтожена практически полностью, подстилающие ее конгломераты обнажены. Карбонатный цемент подвергается растворению атмосферными осадками, что приводит к распространению кластокарста. Восстанавливающаяся на заповедном участке плато степная растительность если и сдерживает этот процесс, то до сих пор в крайне незначительной степени. Вследствие этого происходят обвалы конгломератов и на отвесных стенах каньона появляются ниши и гроты [11]. Антропогенный пресс усугубляется еще и тем, что по охраняемой территории проложены автодорога, которая активно используется в туристический сезон, и арык, снабжающий водой кордон заповедника.

Склоны каньона, напротив, сохранили свой первозданный облик. Они покрыты лесом, в том числе уникальными зарослями дикой яблони [9]. Несмотря на значительную крутизну, они весьма устойчивы к денудации, для них не характерны массовые смещения, о чем говорит малое количество обломочного материала, поступающего к руслу р. Аксу. Исключение составляет крупный оползень - обвал на правом борту в верховье каньона.

Переходная зона представлена крупными, сложно построенными тектоническими уступами, природа которых определена глыбовым характером новейших горообразовательных движе- 


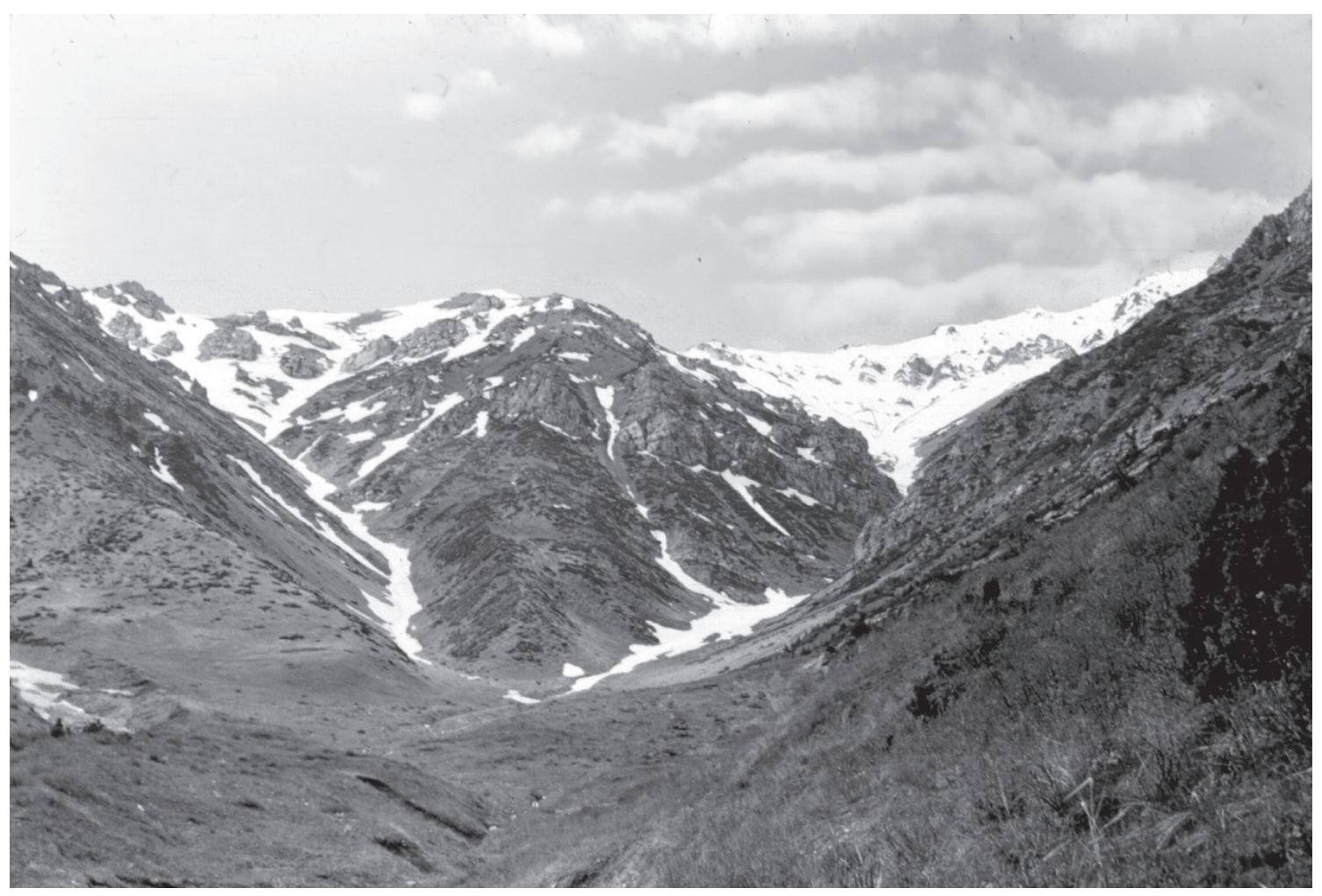

Рис. 4. Лавинные аппараты в урочище Улькен-Каинды.

ний. Выделяются два разноориентированных участка этой зоны, которые в месте стыка образуют почти прямой угол в районе западного окончания Алатау (верховья Ирису, Ргайлы и Жетымсая): субширотный северный участок - между высокогорьем Алатау и среднегорьем Джабаглы, и субмеридиональный западный участок - при переходе высокогорья к плато и окружающему его плоскогорью. Геоморфологическое строение зоны сочетает как переходные варианты между разделяемыми этими зонами типами рельефа, так и специфические, присущие только ей черты.

Наиболее интересен северный участок, поскольку он почти полностью попадает в охраняемую территорию. Меридиональный отрезок служит западным ограничением хр. Алатау, Балдабректау и крупного отрога Угамского хр. (ур. Бахраук, Сильбили), принципиально не отличается от субширотного и потому специально в этой статье не рассматривается. Зона перехода здесь имеет ширину от 1 до 6 км. Она представляет собой северный макросклон хр. Алатау, круто обрывающийся к плоскогорью на левобережье Джабаглы. Контраст высот выражается следующими значениями: от 3500 до 2500 м над ур. м. на востоке (ур. Топшаксаз, Курсай) и от 3100 до 1800 м над ур. м. на западе (ур. Кши-Каинды, Жетымсай). Макросклон расчленен глубокими кру- тосклонными долинами, которые, в отличие от долин описанных выше типов горного рельефа, имеют относительно широкие (30-150 м) плоские днища. Слагающие макросклон породы сильно раздроблены тектоническими подвижками в зоне взбросо-надвига и легко поддаются перемещению лавинами, селями, осыпями и оползнями. Очевидно, что пик активности процессов на склонах приходился на время интенсивного хозяйственного освоения долины Джабаглы, и главным инструментом антропогенного стресса служил выпас, который сопровождался уничтожением древесно-кустарниковой растительности на доступных относительно пологих склонах.

Заповедный режим способствовал частичному восстановлению на склонах лесов и кустарников, равно как и горной степи, что в свою очередь привело к существенной стабилизации гравитационных процессов и зарастанию обломочных шлейфов на склонах. Наиболее значительные события на северном склоне Алатау в настоящее время связаны только со снежными лавинами, поэтому в качестве одного из объектов НСС нами был выбран конус выноса лавинного лотка в ур. УлькенКаинды (рис. 4).

Другой тип рельефа, характерный для переходной зоны, представлен крупными понижениями у подножия Алатау, которые имеют хаотиче- 


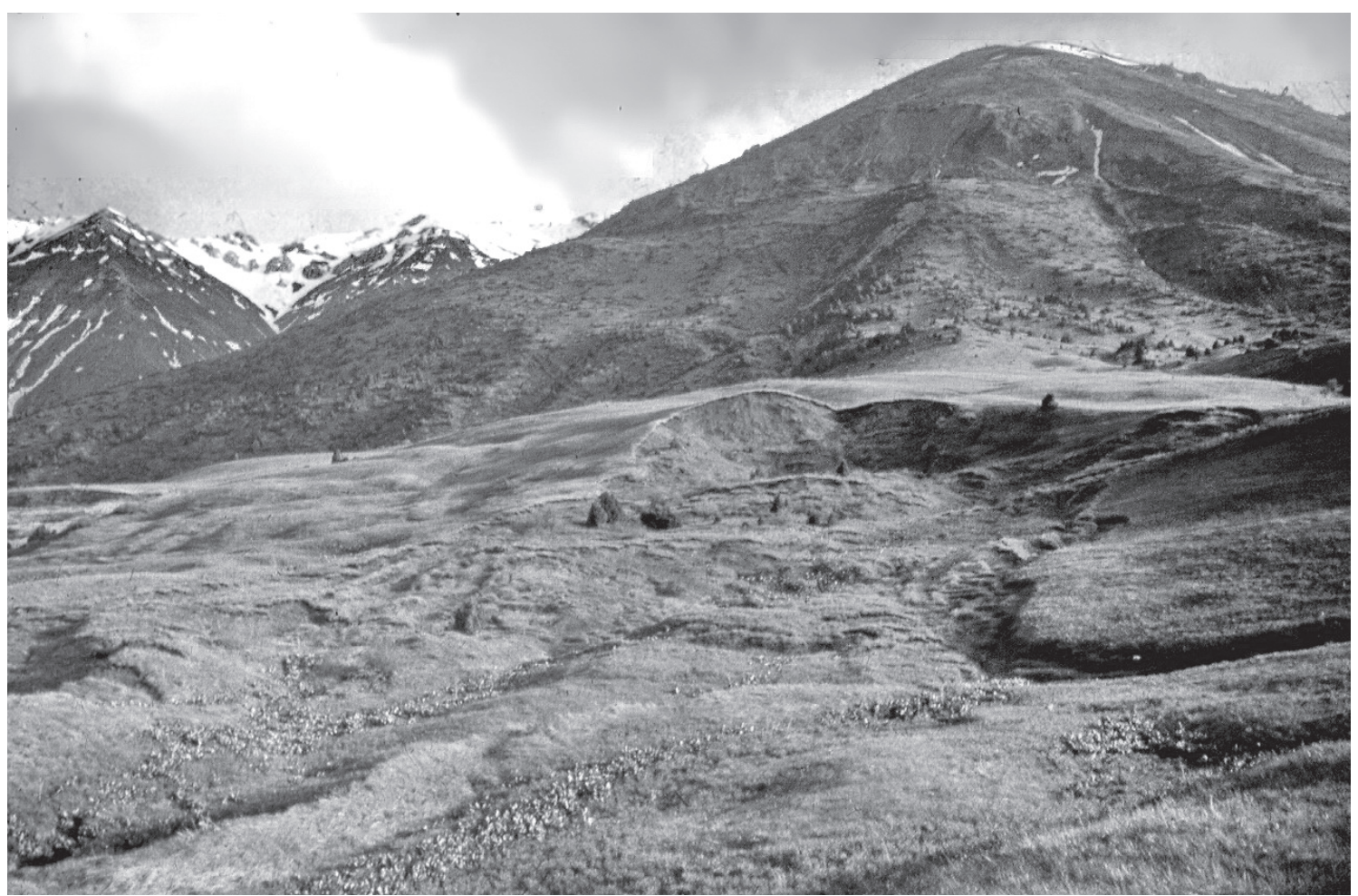

Рис. 5. Оползневой цирк в урочище Улькен-Каинды.

скую бугристо-западинную морфологию ${ }^{3}$. Таких урочищ выделяется семь: Топшаксаз, Курсай, Айнаколь, Кызульген, Улькен-Каинды, Кзылжар и Жетымсай. В них сосредоточены мощные толщи кайнозойских опесчаненных суглинков и элювиальные россыпи коренных пород; все эти отложения сильно переработаны оползневыми процессами.

Поскольку у подножия Алатау происходит выклинивание подземных вод, районы развития оползней постоянно переувлажнены, некоторые западины заняты мелкими водоемами или в них формируются горные болота - сазы. В летописи природы заповедника регулярно отмечается оползневая активность в переходных зонах $[7,14]$. Например, крупный оползень на правом борту р. Саркрама (приток Джабаглы) в 1958 г. перегородил русло и вызвал прохождение селевого потока по долине Джабаглы вплоть до выхода ее на подгорную равнину за пределами заповедника. Однако судя по информации из Летописи, а также по нашим наблюдениям оползни существенно активизировались, начиная с $70-\mathrm{x}$ и особенно в 80-х годах XX в.

Они послужили причиной деформации дорог, троп, поступления крупных масс грунтов в русла

\footnotetext{
${ }^{3}$ В литературе [8 и др.] иногда встречается ошибочное мнение о том, что бугристо-западинный рельеф переходной зоны имеет ледниковое (морена) происхождение.
}

ручьев с последующей генерацией селевых потоков, обрушения деревьев и кустарников и пр.

В ноябре 1979 г. в ур. Жетымсай сотрудники заповедника обнаружили 4 новых оползня. Для наблюдения за их динамикой были заложены две пробных площадки. За три года длина одного из оползней увеличилась на 23 м (до 99 м), другого на 2.5 (до 57.5 м) [7].

Нами в 1982-1984 гг. были зафиксированы резкие подвижки грунтов в ур. Улькен-Каинды. Два крупных оползневых цирка были выбраны в качестве объектов НСС (рис. 5). Мы связываем активизацию оползней с увеличением обводненности рыхлых отложений, что, в свою очередь, связано не столько с климатическими факторами, сколько с зарастанием понижений и окружающих их склонов гор после того, как в долине Джабаглы в 1970-х годах были окончательно прекращены выпас и сенокошение [6, 13]. Это способствует удержанию снежного покрова и влаги в грунтах [1].

\section{ВЫВОДЫ}

Заповедный режим, установленный в отрогах Таласского Алатау более 90 лет назад, оказал существенное влияние на ход геоморфологических процессов. Его воздействие сказывается практически на всех высотных ярусах и типах горного 
рельефа, проявляясь практически во всех видах экзогенного рельефообразования, причем тенденции имеют разную направленность - как в сторону замедления и прекращения функционирования процессов, так и в сторону их активизации. Преобладает тенденция к стабилизации, при этом выстраивается закономерность: от практически нулевого воздействия или незначительной активизации гравитационных процессов в альпийском высокогорье вниз по склонам наблюдается переход к усиливающемуся сдерживанию движения вещества по склонам, вплоть до полного его прекращения. Исключение составляют переувлажненные участки в тектонически активных зонах, где оползневые процессы демонстрируют обратную тенденцию.

\section{ФИНАНСИРОВАНИЕ}

Работа выполнена в рамках темы Государственного задания "Палеогеографические обстановки четвертичного периода и рельефообразующие процессы как основа современных ландшафтов и фактор жизнедеятельности древнего и современного человека” № 01482019-0005, № AAAA-A19-119021990091-4.

\section{FUNDING}

The work was carried out within the framework of the state-ordered research themes of the Institute of Geography RAS, no. 0148-2019-0005 ("The paleogeographic settings of the Quaternary and the relief-forming processes as the basis of modern landscapes and the factor of vital activity of ancient and modern man").

\section{СПИСОК ЛИТЕРАТУРЫ}

1. Буланов С.A. Катастрофические геоморфологические процессы во внутриконтинентальных горных системах // Нелинейность рельефообразующих процессов и экстремальные ситуации (регионально-практические аспекты). М.: РФФИ, РАН. 1996. C. $50-59$.

2. Буланов С.A. Геоморфологические исследования Института географии АН СССР в заповеднике Ак-
су-Джабаглы // Тр. Аксу-Джабаглинского гос. заповедника. Алматы. 2016. Вып. 11. С. 84-93.

3. Буланов C.A. Рельеф заповедника Аксу-Джабаглы // Тр. Аксу-Джабаглинского гос. заповедника. Алматы. 2016. Вып. 11. С. 94-107.

4. Буланов С.А., Горелов С.К. Урал, Центральный Казахстан, Средняя Азия // Геоморфологические режимы Евразии. М.: Медиа-ПРЕСС, 2006. С. 172-203.

5. Геоморфологическая карта СССР м-ба $1: 2500000$ / под ред. И.П. Герасимова. М.: ГУГК, 1986. 16 л.

6. Ковшарь А.Ф. Об антропогенном воздействии на природные комплексы заповедника Аксу-Джабаглы (по страницам Летописи природы заповедника) // Тр. заповед. Аксу-Джабаглы. Алматы. 1996. Вып. 7. С. 32-49.

7. Ковщарь А.Ф., Иващенко А.А., Чаликова Е.С. АксуДжабаглинский заповедник как полигон для проведения научных экспедиций // Тр. Аксу-Джабаглинского гос. заповедника. Алматы. 2016. Вып. 11. C. 37-63.

8. Масальский А.П. Растительность скал и осыпей заповедника Аксу-Джабаглы // Тр. заповед. АксуДжабаглы. 1948. Вып. 1. Алма-Ата. С. 21-35.

9. Нехаенко Г.Н., Чаликова Е.С. Динамика территории и лесного фонда заповедника Аксу-Джабаглы // Тр. заповедника Аксу-Джабаглы. Вып. 7. Алматы: Конжык, 1996. С. 18-31.

10. Шапошников Р.Д. Петроглифы в горах Западного Тянь-Шаня // Бюлл. МОИП. Отд. биол. 1974. Т. 79. Вып. 2. С. 17-21.

11. Полуэктов В.И. Пещеры Аксу-Джабаглинского заповедника // Тр. заповедников Казахстана. АлмаАта. 1973. T. 3. С. $47-53$.

12. Сезин В.М. Распространение снежных лавин в гоpax Западного Тянь-Шаня и их синоптико-статистический прогноз. Автореф. дис. ... канд. геогр. наук. Ташкент: САНИГМИ, 1984. 188 с.

13. Чаликова E.C. Из истории антропогенных воздействий на территорию заповедника Аксу-Джабаглы (Казахстан). http://ecoethics.ru/old/b81/16.html (дата обращения 05.01.2020).

14. Шевченко В.В. Государственный заповедник АксуДжабаглы (эколого-фаунистический очерк) // Тр. гос. заповедника Аксу-Джабаглы. 1948. Вып. 1. Алма-Ата. С. 4-19.

\title{
Protected Mode Influence on the Mountain Relief Development in Central Asia (the Case of Aksu-Zhabagly Nature Reserve)
}

\author{
S. A. Bulanov ${ }^{*}$ \\ Institute of Geography RAS, Moscow, Russia \\ "e-mail: bulanov@igras.ru
}

\begin{abstract}
The oldest nature reserve in the mountains of Central Asia Aksu-Zhabagly Nature Reserve was created more than 90 years ago. During this period, the conservation regime had a significant impact not only on biota, but also on exogenous processes in the reserve. In order to assess this influence, the staff of the Institute of Geography RAS conducted special geomorphological studies. A typological zoning of the reserve's mountain relief was carried out in all high-altitude tiers: highlands, middle mountains and lowlands. A transitional zone characterizing large tectonic benches has been identified. For each type of relief, characteristic changes in the
\end{abstract}


course of geomorphological processes associated with the cessation of anthropogenic pressure, mainly in the form of grazing and the establishment of a specially protected area, are determined. It was established that the general tendency to stabilize the slopes prevails, more noticeable in the mountains' lower tier and practically absent in the high mountains. The reverse trend to processes intensify is noted in two geomorphological settings: in the Alpine highlands and in the foci of landslide development in the transition zone from the highlands to the middle mountains.

Keywords: high mountains, middle mountains, lowlands, exogenous processes, avalanches, mudflows, landslides, grazing, activation, stabilization

\section{REFERENCES}

1. Bulanov S.A. Catastrophic geomorphological processes in the intracontinental mountain systems. In $\mathrm{Ne}$ lineinost' rel'efoobrazuyushchikh protsessov $i$ ekstremal'nye situatsii (regional'no-prakticheskie aspekty) [Nonlinearity of Relief-Forming Processes and Extreme Situations (Regional and Practical Aspects)]. Moscow: Ross. Fond Fundam. Issled., Akad. Nauk, 1996, pp. 50-59. (In Russ.).

2. Bulanov S.A. Geomorphological studies of the Institute of Geography of the USSR Academy of Sciences in the reserve Aksu-Zhabagly. Trudy Zapovednika AksuDzhabagly, 2016, no. 11, pp. 84-93. (In Russ.).

3. Bulanov S.A. Relief of the reserve Aksu-Zhabagly. Trudy Zapovednika Aksu-Dzhabagly, 2016, no. 11, pp. 94107. (In Russ.).

4. Bulanov S.A., Gorelov S.K. Ural, Central Kazakhstan, Central Asia. In Geomorfologicheskie rezhimy Evrazii [Geomorphological Regimes of Eurasia]. Moscow: Media-PRESS Publ., 2006, pp. 172-203. (In Russ.).

5. Geomorphological Map of the USSR in Scale $1: 2500000$. Gerasimov I.P., Ed. Moscow: GUGK, 1986. 16 p. (In Russ.).

6. Kovshar' A.F. On the anthropogenic impact on the natural complexes of the reserve Aksu-Zhabagly (through the pages of the Chronicle of the nature of the reserve). Trudy Zapovednika Aksu-Dzhabagly, 1996, no. 7, pp. 32-49. (In Russ.).
7. Kovshar' A.F., Ivashchenko A.A., Chalikova E.S. Aksu-Zhabagly reserve as a testing ground for scientific expeditions. Trudy Zapovednika Aksu-Dzhabagly, 2016, no. 11, pp. 37-63. (In Russ.).

8. Masal'skii A.P. The vegetation of rocks and scree of the reserve Aksu-Zhabagly. Trudy Zapovednika Aksu-Dzhabagly, 1948, no. 1, pp. 21-35. (In Russ.).

9. Nekhaenko G.N., Chalikova E.S. Dynamics of the territory and forest fund of the reserve Aksu-Zhabagly. Trudy Zapovednika Aksu-Dzhabagly, 1996, no. 7, pp. 18-31. (In Russ.).

10. Shaposhnikov R.D. Petroglyphs in the mountains of the Western Tien Shan. Byull. MOIP, Otd. Biol., 1974, vol. 79, no. 2, pp. 17-21. (In Russ.).

11. Poluektov V.I. The caves of Aksu-Zhabagly reserve. Trudy Zapovednika Aksu-Dzhabagly, 1973, no. 3, pp. 47-53. (In Russ.).

12. Sezin V.M. Spread of avalanches in the mountains of the Western Tien Shan and their synoptic and statistical forecast. Cand. Sci. (Geogr.) Dissertation. Tashkent: Sci. Res. Hydrometeorol. Inst. (NIGMI) of Uzhydromet, 1984. $188 \mathrm{p}$.

13. Chalikova E.S. From the history of anthropogenic impacts on the territory of the reserve Aksu-Zhabagly (Kazakhstan). Available at: http://www.ecoethics.ru/old/b81/16.html (accessed: 05.01.2020). (In Russ.).

14. Shevchenko V.V. Aksu-Zhabagly State Reserve (ecological-faunistic essay). Trudy Zapovednika Aksu-Dzhabagly, 1948, no. 1, pp. 4-19. (In Russ.). 